\title{
Subnational institutionals, political capital, and the internationalization of entrepreneurial firms in emerging economies
}

Article

Accepted Version

Creative Commons: Attribution-Noncommercial-No Derivative Works 4.0

Ma, X., Ding, Z. and Yuan, L. (2016) Subnational institutionals, political capital, and the internationalization of entrepreneurial firms in emerging economies. Journal of World Business, 51 (5). pp. 843-854. ISSN 1090-9516 doi:

https://doi.org/10.1016/j.jwb.2016.07.004 Available at https://centaur.reading.ac.uk/70986/

It is advisable to refer to the publisher's version if you intend to cite from the work. See Guidance on citing.

Published version at: https://doi.org/10.1016/j.jwb.2016.07.004

To link to this article DOI: http://dx.doi.org/10.1016/j.jwb.2016.07.004

Publisher: Elsevier

All outputs in CentAUR are protected by Intellectual Property Rights law, including copyright law. Copyright and IPR is retained by the creators or other copyright holders. Terms and conditions for use of this material are defined in the End User Agreement. 


\section{CentAUR}

Central Archive at the University of Reading

Reading's research outputs online 


\title{
Subnational institutional environment, political capital, and internationalization of
}

\section{entrepreneurial firms in emerging markets}

\author{
Xufei Ma \\ Department of Management \\ The Chinese University of Hong Kong \\ Shatin, N.T., Hong Kong \\ E-mail: xufei@cuhk.edu.hk
}

\author{
Zhujun Ding* \\ Department of Leadership, Organisations and Behaviour \\ Center for Entrepreneurship \\ University of Reading \\ E-mail: dingzhujun@gmail.com
}

\author{
Lin Yuan \\ Department of Management and Marketing \\ University of Macau \\ Avenida Padre Tomas Pereira, Taipa, Macau \\ E-mail: linyuan@umac.mo
}

*Corresponding author. 


\title{
Subnational institutional environments, political capital, and the internationalization of entrepreneurial firms in emerging economies
}

\begin{abstract}
This study advances the institution-based view of strategy by integrating it with firmspecific capability considerations. In particular, we investigate the integrative influence of subnational-level home country institutional environments and firm-level political capital, as an important way to seek resources, on emerging economy entrepreneurial firms' internationalization. With data from Chinese entrepreneurial firms, we find that the development of subnational institutional environments in the home country is related to firms' degree of internationalization. Furthermore, while political capital with low-level governments enhances the effect of subnational institutions on internationalization, political capital with high levels of government has no such moderation effect. Theoretical and empirical contributions and implications are discussed.
\end{abstract}

Keywords: Institutional theory; Subnational institutional environment; Political capital; Internationalization; Entrepreneurial firms; Emerging economies 


\section{Introduction}

How do environmental factors affect entrepreneurial firms' internationalization strategies? Grounded in the industry-based view and an emerging institution-based view, extant research has investigated the influence of host country environments on firm internationalization in a range of settings (e.g., Ahlstrom, Levitas, Hitt, Dacin, \& Zhu, 2014; Dikova, Jaklič, Burger, \& Kunčič, 2016; Hitt, Li, \& Xu, 2016). Other recent work shows how home country environments, in particular country-level institutional environments, exert important influences on firms' actions regarding internationalization and performance (Meyer, Estrin, Bhaumik, \& Peng, 2009; Wan \& Hoskisson, 2003; Yamakawa, Peng, \& Deeds, 2008). However, little is known about the influence of subnational institutions in the home country on firms' internationalization strategies. This gap is important because there is an uneven distribution of institutional development across subnational regions in many countries, including large emerging countries (Chan, Makino, \& Isobe, 2010a). In addition, other differentiating factors, such as different subcultures and dialects, exist (Gong, Chow, \& Ahlstrom, 2011; Redfern \& Crawford, 2010). Relatedly, the strategic management and international business literature streams have shed increasing light on the effects of subnational regions on firm performance (Chan et al., 2010a; Ma, Tong, \& Fitza, 2013). Thus, the main purpose of this study is to join these research streams by examining how the within-home-country variations of institutions influence firms' internationalization strategies.

This study focuses on the internationalization strategies of emerging economy entrepreneurial firms. In particular, we argue that (1) well-established subnational institutional environments in emerging economies can have a positive effect on 
entrepreneurial firms' internationalization and (2) such an effect is contingent on individual firms' resource-seeking strategies. We investigate the role of entrepreneurial firms' political capital, with both high- and low-level governments in the home country (Ahlstrom, Bruton \& Lui, 2000; $\mathrm{Lu} \& \mathrm{Ma}, 2008)$, as an important resource-seeking strategy. The differentiation of political capital is consistent with recent research showing that firms must deploy the network in a cohesive and coordinated way to facilitate globalization strategies (Hatani \& McGaughey, 2013).

This study tests the hypotheses using biennial-surveyed longitudinal data of a sample of 760 Chinese entrepreneurial firms from 2002 to 2006 . The substantive variation of within-country institutional environments, the critical role of the Chinese government in economic activities, the active deployment of political capital, and the increasing number of multinational corporations (MNCs) from China all provide an appropriate empirical context to test the research model proposed in this study.

The study makes several contributions to international business research and practice. First, we offer evidence of the importance of a firm's geography for its strategic choice, particularly identifying the impact of subnational institutions. Our study is consistent with a growing stream of research that explicitly recognizes the strategic role and implication of MNCs' home country geographic location (Sölvell, 2015; Wan \& Hoskisson, 2003; Yamakawa et al., 2008). This article aims to extend that work by demonstrating the presence and importance of subnational institutions and their impact on shaping the internationalization strategy of entrepreneurial firms embedded within the context. One contribution of this study therefore lies in integrating the international business literature with subnational geography studies. 
Second, this study contributes to theory by extending the institution-based view of strategy (Peng, Sun, Pinkham, \& Chen, 2009) to examine the interactive effect of subnational institution with firm-level strategy. Rather than treating firms as passive recipients of benefits from strong (and uniform) institutions, we view them as active participants trying to exploit advantages from their varied institutional environments in their home country. ${ }^{1}$ Research has long argued that political capital facilitates the performance of firms in various ways (e.g., Ahlstrom, Bruton, \& Yeh, 2008; Dunbar \& Ahlstrom, 1995; Peng \& Health, 1996). Firms try to deploy different types of political capital to effectively gain resources from home country institutional environments (Ahlstrom et al., 2000). Specifically, we differentiate between political capital with high and low levels of government; indeed, high and low levels of government differ greatly in organizational size, responsibility, authority, and efficiency (Chan et al., 2010a; Higgins, Young, \& Levy, 2009; Li, He, Lam, \& Yiu, 2012; Meyer \& Peng, 2005). Therefore, we argue that different levels of political capital and their effects matter. In particular, we contend that deployment of political capital with high-level governments aids entrepreneurial firms in securing resources from their institutional environments by enhancing their credibility and legitimacy (Ahlstrom et al., 2008). Conversely, deployment of political capital with low-level governments enhances firms' resource-seeking capability by providing key institutional information. Thus, we offer a framework that accounts for both institutions in the home country and entrepreneurial firms' resource-seeking strategy.

Finally, studies in strategic management limit the effects of political capital to the

\footnotetext{
${ }^{1}$ Institutions are considered strong if they support the voluntary exchange underpinning an effective market mechanism (Meyer et al., 2009).
} 
strategic behavior in firms' domestic market, thus largely ignoring their effects in international markets (Faccio, 2010; Faccio, Masulis, \& McConnell, 2006; Wu, 2011; You \& Du, 2012). Given the limited international experience of emerging economy-based entrepreneurial firms, this article provides insights into how and to what extent they utilize political capital across borders, leading to a better understanding of their international strategies (Frynas, Mellahi, \& Pigman, 2006).

\section{Theoretical overview}

\subsection{An institution-based view of internationalization}

Institutions are commonly recognized rules, both formal (e.g., regulations, laws) and informal (e.g., codes of conduct, norms), in a society (North, 1990). Scott (2013) defines institutions as the regulative, normative, and cognitive structures and activities that provide stability and meaning to social behavior. Regulative or legal aspects of institutions most commonly take the form of formal institutions - they guide organizational action by force or threat of legal sanctions - while normative and cognitive institutions generally take the form of informal institutions - they guide organizational actions stemming from social, professional, and cognitive-cultural aspects (Chao \& Kumar, 2010; Scott, 2013). In this sense, institutions structure the economic, political, and social relationships in a society or country and thus determine the transaction and transformation costs of firms embedded within them (Chan et al., 2010a). Therefore, by treating institutions as independent variables, the institution-based view defines firms' strategic choices and performance as the outcome of the economic, political, and social institutions they confront (Meyer et al., 2009; Peng, Wang, \& Yi, 2008; Yamakawa et al., 2008). 
Scholars have documented the growing importance of formal and informal institutions as both constraints and facilitators to strategy across borders (Doh, Luthans, \& Slocum, 2016). Propelled by research on emerging economies, an institution-based view has been influential in the study of internationalization (Holmes, Miller, Hitt, \& Salmador, 2013; Meyer et al., 2009; Yamakawa et al., 2008) and increasingly in entrepreneurship (Bruton, Ahlstrom, \& $\mathrm{Li}, 2010)$. This is because emerging and developed economies can vary significantly in terms of institutional frameworks (Acemoglu \& Johnson, 2005; Acemoglu \& Robinson, 2013; Ahlstrom, Young, Nair, \& Law, 2003). Compared with developed countries, emerging countries are typically characterized by poorer governance and weaker and less efficient formal institutions (Cuervo-Cazurra \& Genc, 2008; De Soto, 1989). These profound differences in institutional frameworks have led scholars to pay more attention to how the institutional environment shapes MNCs' internationalization strategies and performance. For example, recent studies on institutional distance have found that distances on the regulative, normative, and cognitive dimensions of institutions between the host and home countries affect MNCs' strategies pertaining to host country selection, entry mode, and performance (e.g., Chao \& Kumar, 2010; Schwens, Eiche, \& Kabst, 2011; Xu \& Shenkar, 2002). Another stream of research focusing on the home country institutional environment documents that the level of institutional development in the home country may affect firms' tendency to internationalize as well as their performance in internationalization (e.g., Wan \& Hoskisson, 2003; Yamakawa et al., 2008). These two streams of literature agree that national-level institutional environments of either the home or host countries shape MNCs' internationalization strategies and performance.

Studies have also shown that an additional class of institutional environmental factors, 
that is, subnational institutions in home countries, has a statistically significant impact on a foreign subsidiary's choice of entry strategy and performance (e.g., Chan et al., 2010a; Ma et al., 2013; Meyer \& Nguyen, 2005). Arguably, a subnational level allows for a more fine-grained analysis of regional differences, given that subnational regions in an emerging country can differ remarkably in the level of institutional development (Ma et al., 2013; Zhou, Delios, \& Yang, 2002). Despite significant findings, this stream of studies has two limitations. First, little is still known about the role of home country subnational institutions in firms' internationalization strategy making. Second, in viewing firms as the recipients

of the benefits of strong institutions, these studies largely ignore how firms proactively exploit the institutions, in particular the subnational institutions, to gain advantages over competitors under the same institutional environment. We elaborate on this missing link in the institution-based view of internationalization next.

\subsection{The missing link: Both understanding and utilizing institutions}

A well-developed subnational institutional environment may provide opportunities for entrepreneurial firms to gain access to various resources and knowledge related to internationalization, but the achievement of such resources involves a process of exploiting the advantage of institutions. This implies that firms are not merely passive recipients of institutional advantages; rather, they proactively adapt their strategies to develop knowledge and capacity to exploit home country institutions and, thus, to enjoy more exploitation benefits from the institutional context (Ahlstrom et al., 2008; Judge \& Zeithaml, 1992). In particular, the literature emphasizes two requirements for the exploitation of institutional advantages: having broad knowledge of institutions and the capability of utilizing these institutions. 
First, MNCs must have a general awareness of the various institutions, their features, and their usefulness. Well-established institutional environments reduce transaction costs and increase transaction efficiency, thus facilitating firm transactions. However, the extent to which institutions facilitate transactions depends on the level of firms' knowledge of the institutions. The more familiar they are, the better they can exploit the institutions to facilitate transactions.

For example, well-developed institutional environments contain many intermediaries, such as credit-rating agencies, investment analysts, merchant bankers, venture capital firms, search and recruiting agencies, and marketing research and advertising companies, through which entrepreneurial firms can gain access to various resources in product, labor, and capital markets (Khanna, Palepu, \& Sinha, 2005). Thus, firms need to identify potential intermediaries through which they can gain resources more effectively and learn to assess and cooperate with potential intermediaries (Young, Ahlstrom, Bruton, \& Rubanik, 2011), both of which increase the search, negotiation, and contracting costs of firms. The lack of knowledge of institutional environments thus magnifies transaction costs (Henisz \& Delios, 2002; Meyer, 2001; Oxley, 1999).

Empirical studies also provide empirical support for the importance of understanding institutional environments. For example, Henisz and Delios (2001) find that Japanese MNCs tend to eschew politically hazardous countries, with the effect strongest for firms without experience in the host country and without experience gathered from international investments in other countries. These results underscore the importance of both the institutional environment and firm-specific capability as determinants of entry. Indeed, although understanding the institutional environment is a necessary condition for firms to 
gain access to institutional benefits, it is not sufficient (Bruton, Ahlstrom, \& Puky, 2009).

The second requirement is that firms must have the capability of exploiting and utilizing the opportunities the institutional environment offers. When an institutional environment is not well-established, firms may need to rely more on network- or relationbased strategies to develop the ability to fill the institutional voids. For example, Khanna and Palepu (2000) find that at higher levels, industry diversification of Indian business groups is positively related to affiliated firms' performance, because a diversification strategy can help fill institutional voids in emerging economies.

The capability of exploiting institutional benefits is also important in a well-developed institutional context. In strong institutional environments, firms can face information asymmetries (Arrow, 1971; Buckley \& Casson, 1998), asset specificity (Williamson, 1985), or costly transfer of tacit knowledge (Kogut \& Zander, 1993; Teece, 1977), which requires them to develop capabilities to enhance competitiveness and manage the environments. The lack of capabilities in this way magnifies transaction costs. For example, Peng and Hao (2011) confirm that firms that enter developed countries but ignore foreign institutions may lose legitimacy in the face of an international crisis or even low-level conflict.

In summary, the integration of the institution-based view with institution exploitation capability can better predict how the institutional environment shapes MNCs' internationalization behavior and consequent performance. The institution-based view speaks to MNCs' location advantages insofar as institutions are most conducive to their business operations. However, these advantages might not materialize if firms lack the relevant capability of recognizing institutional variation (Carney, Gedajlovic, \& Yang, 2009) and proactively managing the institutional environment and institutional differences, 
particularly at the local and regional levels (Ahlstrom et al., 2003; Peng et al., 2009; Poncet, 2005).

\section{Hypotheses development}

\subsection{Home country subnational institutions}

Institutions are commonly understood as the formal and informal "rules of the game in a society" (North, 1990, p. 3). Consistent with the institution-based view, prior studies have found that a country's institutional environment partially shapes firms' strategies (Hitt, Ahlstrom, Dacin, Levitas, \& Svobodina, 2004) and approaches to internationalization and product diversification (Makino, Isobe, \& Chan, 2004; Peng et al., 2009; Peng et al., 2008; Wan \& Hoskisson, 2003).

With many countries' gradual shift from centrally planned to market-based economies in recent years (Peng \& Heath, 1996), large subnational regional differences have emerged in the level of their institutional development (Chan et al., 2010a; Chan, Lin, \& Wong, 2010b; Li et al., 2012; Ma et al., 2013). Complementing studies that emphasize the countrylevel institutional environment, a limited stream of literature shows that the subnational institutional environment in a host country matters for the performance of MNCs (Ma et al., 2013; McGahan \& Victer, 2010; Poncet, 2005). Subnational regions in a country vary in aspects such as economic, political and legal, and social institutions, which govern business transactions and thus affect the strategy and performance of firms embedded within the local context (Meyer et al., 2009; Peng et al., 2009; Peng et al., 2008).

Wan and Hoskisson (2003) find that the factors and institutions in the home country also differ, representing diverse sets of opportunities and constraints for firms, and thus 
affect firms' diversification strategy making. This suggests a need to extend the literature on host country subnational institutional environments by considering the effect of home country subnational institutional environments. Drawing from the institution-based view, we suggest that the home country subnational institutional environment affects internationalization decision making from at least four perspectives.

First, economic institutions generally involve the supply of intermediaries and infrastructures in product, labor, and capital markets (Khanna \& Palepu, 1997; Khanna et al., 2005). Subnational regions in a country can differ markedly in the abundance level of economic institutions, with some regions suffering more from economic institutional voids, leading to location advantages of some regions over others in a country (Kambhampati \& McCann, 2007; Ma et al., 2013; Meyer \& Nguyen, 2005). With well-established economic institutions in a region, it is easier for entrepreneurial firms to gain access to reliable information on consumers, product quality and features, creditors and investors, and quality of talent from regional markets (Khanna et al., 2005). Well-established information systems help reduce information asymmetries, thus lowering the cost of searching for information needed for internationalization ( $\mathrm{Lu}, \mathrm{Xu}, \& \mathrm{Liu}, 2009)$. Such institutions also allow entrepreneurial firms to gain access to various local resources that support their internationalization, such as financial capital and talent, with lower cost and less uncertainty. Moreover, efficient dissemination of product information enables entrepreneurial firms to establish credible brand names at lower cost (Khanna \& Palepu, 1997; Khanna et al., 2005), which in turn facilitates their internationalization.

The second effect is government policy at the subnational level, with a focus on formal rules and the effectiveness and credibility of a region's power center, which regulates 
business transactions (Ma et al., 2013; Wan \& Hoskisson, 2003). In the emerging economy of China, several provincial and municipal governments, following the decentralization of the economic system in 1984, have played an important role in pushing many local firms into overseas investment activities, to obtain capital, technology, taxation income, and trade support for their respective local and regional development strategies (Cai, 1999; Luo, Xue, \& Han, 2010). Consequently, subnational regions in emerging economies exhibit significant heterogeneity in the development of outward foreign direct investment (OFDI) policies, with some economically developed regions launching such policies more successfully than others. Chinese firms from these subnational regions are encouraged to expand overseas because, with the local government's political (and in some cases, financial) support, they can gather information on foreign business opportunities and market conditions and raise money quickly from local creditors.

Third, subnational regions in emerging economies are likely to be heterogeneous in agglomeration of foreign MNCs (Ma et al., 2013; Meyer \& Nguyen, 2005; Zhou et al., 2002). For example, Meyer and Nguyen (2005) find that foreign investors are more likely to invest in subnational regions with more developed market-supporting institutions. In these regions, intense competition among foreign MNCs may drive domestic entrepreneurial firms to seek opportunities abroad to avoid clashing with firms in their home market (Dawar \& Frost, 1999; Mascarenhas, 1986). The entry of foreign MNCs in a region also has spillover effects on domestic firms (Blake, Deng, \& Rod, 2009; Wei \& Liu, 2006). Consistent with the learning advantage of newness, emerging market-based entrepreneurial firms could learn new and advanced knowledge and practice from foreign MNCs to compensate for their competitive disadvantages in international markets (Blake 
et al., 2009; Blomstrom \& Kokko, 1998; Nicolini \& Resmini, 2010; Wei \& Liu, 2006). Therefore, entrepreneurial firms based in well-regulated subnational regions may have more opportunities to gain access to resources and knowledge required for competing in international markets and thus have higher levels of internationalization.

Fourth, regional social institutions, which generally involve the informal values and norms in the region, constrain the choice of action and facilitate acceptable and preferred behavior by members of a society (Chan, Isobe, \& Makino, 2008; Gong et al., 2011). Evidence indicates that some subnational regions in China are growing more defiant against bureaucratic control by the central government and exhibit more openness in social values toward going global and building related commercial and cultural international links (Sheng, 2007). Such open beliefs and values about going global in the region contribute to entrepreneurial firms' capability building (Saxenian, 1994) and enhance their motivation to get involved in a higher level of international expansion (Yamakawa et al., 2008).

In summary, regional economic, political, and social institutions form the institutional environment at the subnational level from which entrepreneurial firms can gain access to resources and knowledge related to internationalization. Thus, a well-developed subnational institutional environment may foster and facilitate internationalization activities. Thus:

Hypothesis 1. The development of subnational institutions in the home country exerts a positive effect on emerging economy entrepreneurial firms' degree of internationalization.

\subsection{The moderating effects of political capital}

The previous argument implies that though our theoretical framework should hold for emerging economy entrepreneurial firms, some firms are more capable than others of 
spotting, recognizing, and exploiting the opportunities in the subnational institutional environment. One potential dimension that can moderate the exploitation of institutional benefits is a firm's political capital, which serves as a "helping hand" to better gain access to resources from the home country environment (Che \& Qian, 1998; Jun \& Girma, 2010).

We differentiate two types of political capital because of their unique features: political capital with high and low levels of government. As a result of successive waves of decentralization in China, high-level (including the central and provincial-level) and low-level (including municipal-, county-, and township-level) governments show significant differences in size, responsibility, authority, and efficiency (Chan et al., 2010b; Chien, 2010; Higgins et al., 2009; Li, Cui, \& Lu, 2014; Li et al., 2012; Meyer \& Peng, 2005; Pepinsky \& Wihardja, 2011; Xu, 2011; Zhan, 2009). Accordingly, prior studies have found that business connections with high and low levels of government influence business activities differently (Che \& Qian, 1998). Because of the difference in their characteristics, political capital with high- and low-level governments helps entrepreneurial firms exploit institutional advantages in different ways.

Governments in some emerging economies, such as China, have long supported large and established firms, especially state-owned firms, over small firms (Voss, Buckley, \& Cross, 2010; Yamakawa et al., 2008). As a result, direct help, such as financial aid and preferential treatment from the government, is rare for entrepreneurial firms. However, political capital with high-level governments could improve entrepreneurial firms' capability of gaining resources from the home country environment by enhancing their legitimacy and credibility (Wu, 2011).

As argued previously, entrepreneurial firms based in regions with well-developed 
institutions have access to resources and knowledge required for competing in international markets, leading to a higher level of internationalization. Such access can also arise for entrepreneurial firms with a high level of political capital because of their better credibility and legitimacy (Ahlstrom et al., 2008). For example, investors tend to believe that politically connected entrepreneurial firms have a low bankruptcy risk, which makes it easier and cheaper for these firms to secure financial capital from well-developed capital markets (Chan, Dang, \& Yan, 2012; Faccio et al., 2006; Francis, Hasan, \& Sun, 2009; Liu, Uchida, \& Gao, 2012) and weather financial downturns (Bruton, Peng, Ahlstrom, Stan, \& $\mathrm{Xu}, 2015)$.

High legitimacy of entrepreneurial firms also leads to customer acceptance of their products and technologies (Ahlstrom et al., 2008; Suchman, 1995; Wu, 2011), thus helping them establish their brand names, which in turn facilitates access to resources in a developed product market during internationalization. Furthermore, politically connected entrepreneurial firms are more attractive to experienced workers than non-connected firms because of their higher growth opportunities (Faccio, 2010; Faccio et al., 2006; Fan, Wong, \& Zhang, 2007). Therefore, in well-established labor markets, entrepreneurial firms with political capital with high-level governments have better access to talent.

In summary, political capital with high-level governments improves entrepreneurial firms' capability of gaining access to resources from subnational institutional environments by enhancing their credibility and legitimacy. In turn, this capability strengthens the influence of subnational home country environments on internationalization. Thus:

Hypothesis 2. Emerging economy entrepreneurial firms' political capital with highlevel governments positively moderates the relationship between the development of subnational institutions and firms' degree of internationalization. 
As argued previously, firms' exploitation of institutional benefits requires better knowledge of the institutional environment. That is, entrepreneurial firms must be able to search and evaluate the information on the subnational institutional environment. This knowledge search and transfer process could be enhanced by the deployment of political capital with a low-level government. Specifically, with the government decentralization in China, many decision-making responsibilities (e.g., local industrial policy) now fall to lowlevel governments (Chien, 2010; Oi, 1995), and thus low-level governments tend to have more specific information about regional institutions. Connections with low-level governments may enhance entrepreneurial firms' access to information on subnational institutions from at least three channels, thus facilitating their internationalization.

First, firms with connections with low-level governments tend to receive more help in the knowledge search phase because low-level governments have better knowledge about regional institutional environment. For example, local government offices inform potential local investors about foreign business opportunities, market conditions, and legal and taxation issues (Voss et al., 2010). Local governments also help firms attain credible information about local environments, such as policy shifts and industry reforms. Moreover, in some emerging economies, such as China, firms may need government approval to go abroad. Entrepreneurial firms with local government connections might receive exclusive information about these government policies and administrative procedures (Frynas et al., 2006; Li et al., 2012; Okhmatovskiy, 2010; Wei, Hou, Wang, \& Wang, 2011). Therefore, deployment of political capital with low-level governments can facilitate entrepreneurial firms' information search about institutional environments.

Second, compared with those in high-level government, officials in local governments 
tend to be more enthusiastic and proactive in promoting OFDI by local firms because they can share in subsequent benefits, such as the regional "openness" ranking (the higher OFDI from the region, the higher is the global openness of the region), increased exportation fostered by OFDI, and taxation income sharing from expanded businesses (Higgins, Levy, \& Young, 2006; Li et al., 2014; Luo et al., 2010; Vries, 2008); these factors all directly influence the well-being and promotion of officials in local governments. As a result, local officials are motivated to turn the administrative bureaucracy (of which they are a part) into a free-flowing information channel to facilitate the expansion of local entrepreneurial firms. For example, using information and contacts they have developed through routine administrative work, local officials can provide information on new products, technology, and markets to connected firms (Oi, 1995), which in turn deepens these firms' understanding of the development of product markets and facilitates their internationalization.

Third, local governments in emerging markets, which, as we argued previously, have a better understanding of regional product market, also actively attempt to help politically connected entrepreneurial firms develop cooperation with relevant business associations and other agencies in the region (Voss et al., 2010), which leads to knowledge transfer from these agencies to the firms. As a result, political capital with low-level governments may improve entrepreneurial firms' knowledge about the institutional environment, leading to better exploitation of subnational institutions. Thus:

Hypothesis 3. Emerging economy entrepreneurial firms' political capital with lowlevel governments positively moderates the relationship between the development of subnational institutions and firms' degree of internationalization. 


\section{Methodology}

\subsection{Research site}

China enjoyed an average annual increase of $22.4 \%$ in exports, from 2000 , when the country joined the World Trade Organization, to 2010, in the process of becoming the world's largest exporter with nearly $10 \%$ of the world's total exports (UNCTAD, 2010). As the largest emerging economy, China has been transforming from a centrally planned to a market-based economy through liberalization and privatization since the late 1970s, accompanied by institutional upheaval in the political systems, legal framework, and market structure (Child \& Tse, 2001). Private firms, as part of China's vigorous economic engine, play an important role in facilitating economic development and expanding into international markets (Ahlstrom \& Ding, 2014). However, private firms still face high pressure to gain social legitimacy and support (Ahlstrom et al., 2008; Li, Meng, Wang, \& Zhou, 2008). Without direct financial assistance from the government, private firms in China face severe market competition and institutional turbulence. Therefore, private firms have only recently gained the right to launch international activities directly, and with the unevenly developed subnational institutions, they offer a suitable natural context for testing the theoretical arguments we proposed (Hitt et al., 2004; Ma, Lin, \& Liang, 2011).

More specifically, individual firms are nested within provinces/cities, each of which embraces different subnational institutions, creating a hierarchical data structure with two levels of random variations: variation among individual firms (level 1) and variation among provinces/cities (level 2). To date, institution and internationalization literature has predominantly used ordinary least squares regression to examine the interaction between firm characteristics and environmental (i.e., home and host county) factors. However, this 
approach does not take into consideration the interdependence of lower-level entities nested within higher-level units (Joshi, Liao, \& Jackson, 2006). To avoid this problem, we used multi-level modeling, which is particularly suitable for analyzing data at different levels of analysis and accounts for the nesting of data at one level within another level (Hitt, Hoskisson, \& Kim, 1997; Klein, Dansereau, \& Hall, 1994).

This study tests the effect of higher-level (level 2 or the subnational level) institutions on lower-level (level 1 or the firm level) emerging market entrepreneurial firms' foreign sales intensity and the cross-level interactions between subnational institutions (level 2) and firms' managerial political capital (level 1). We also include control variables to eliminate confounding effects. The present design and analysis improve on existing studies that use multi-level analysis to provide a clearer picture of the dynamic interaction system of the internal and external influence of firm internationalization.

\subsection{Data}

We used valid data from several reliable sources. The firm-level data came from the Biennial Survey of China's Private Enterprises conducted from 2002 to 2006. This is a nationwide survey using a multi-stage stratified random sampling method to achieve a balanced representative sample of firms across all regions and industries in China, conducted by the Chinese Academy of Social Science, All China Industry and Commerce Federation, and the United Front Work Department of the Central Committee of the Communist Party. The survey data contain a sample of Chinese private firms in 14 industries located in 31 regions (i.e., 22 provinces, four province-level municipalities, and five minority autonomous regions). This broad range of local institutional settings allows us to investigate how institutional heterogeneity influences Chinese enterprises across 
provinces. The survey data set is by far the best for examining the effect of subnational institutions on Chinese firms' internationalization, with intensive interviews of entrepreneurs and comprehensive questions about entrepreneurs' backgrounds, family condition, firm history, size, basic financial information, and so on. After eliminating missing data and matching data for different years, we compiled a data set of 1,133 observations.

\subsection{Measures}

\subsubsection{Dependent variable}

Our aim is to investigate firms' internationalization strategies. Therefore, the key variable of interest is foreign sales intensity, measured as foreign sales divided by total sales, with a two-year lag. We used logit transformation on the foreign sales percentage$\mathrm{y}^{\prime}=\ln (\mathrm{y} /[1-\mathrm{y}])$

\subsubsection{Explanatory variables}

At the subnational level, we measured subnational institutions using the Index of Marketization, which was developed by the National Economic Research Institute of the State Council. The index was computed on the basis of data from Chinese statistical yearbooks, reports from the administrations of industry and commerce, and surveys. The index measures the quality of market-supporting institutions at the provincial level and captures the progress of transition from a centrally planned to a market-based economy.

At the individual level are two explanatory variables: political capital with high- and lowlevel governments. Entrepreneurs' political capital reveals their connection with political authorities and the resources to which they gain access (Li \& Zhang, 2007; Park \& Luo, 2001); we measured it as the combination of entrepreneurs' membership in People's 
Congress (PC) and People's Political Consultative Conference (CPPCC) at different levels. We measured political capital with high-level governments as the sum of PC and CPPCC memberships at the provincial and national levels. We assessed political capital with lowlevel governments as the sum of PC and CPPCC memberships at municipal, county, and township levels. As mentioned previously, we adopt multi-level regressions to examine both the effect of the subnational institution and firms' political capital. Especially for testing the effect of political capital, we relied on regression with dummy variables. Drawing from previous research, we defined the dummy variables as D1 equals 1 if a firm has political capital with high-level governments (and 0 otherwise) and D2 equals 1 if a firm has political capital with a low-level government (and 0 otherwise).

\subsubsection{Control variables}

To account for potential confounding at both the subnational and firm levels, we controlled for several variables that might be associated with a firm's foreign strategy. Specifically, we incorporated several firm-specific factors to tease apart their effects on firm foreign sales intensity. We measured Firm size with the natural $\log$ of the employee number and Firm age as the years from the firm's business registration in the survey year. We also determined whether the firm had been restructured from a state-owned enterprise to a private firm and labeled this variable as Restructure. For financial equity, we controlled for Debt equity ratio, and for firm performance, Return on equity. Because foreign ownership might influence firms' international strategies and foreign sales, we also controlled for Foreign equity ratio. We measured firms' technology capability as their $R \& D$ expenditure (Tseng, Tansuhaj, Hallagan, \& McCullough, 2007), as technology capability can foster internationalization (Monreal-Pérez, Aragón-Sánchez, \& Sánchez-Marín, 2012). 
We also controlled for entrepreneurs' Age and Education to eliminate their potential confounding effects.

At the subnational level, we controlled for the population of the subnational region by using the natural log of the population size (LnPopulation). We controlled for Education by using the proportion of the number of people with an education (above primary school) to the total number of adults (older than 6 years of age). To control for the economic development of each subnational region, we added the variable on whether the region is located in the Special economic zone to the model. Finally, we added Patent ratio to the model to control for the potential effect of subnational innovation, by using the ratio of patent granted to total patent applications for each year.

\section{Results}

Table 1 provides the summary statistics and correlation matrix. We checked for the possibility of collinearity among the independent variables by running a variance inflation matrix analysis. The variance inflation factor indices are all below 3, which is much lower than the accepted value of 10 to indicate problems of collinearity (Stata Corporation, 2001).

---- Insert Table 1 about here ----

We used the longitudinal multi-level mixed-effect model to analyze the data. The longitudinal/panel data method allows us to control for individual heterogeneity. To eliminate the risk of obtaining biased results, we controlled for firm-specific heterogeneity by modeling it as an individual effect, which is eliminated when taking the first differences of the variables. We also controlled for year dummy variables, by eliminating time-specific effects, and for industry dummies, representing industry-specific effects. 
Table 2 shows the multi-level regression results. We estimated nested models by starting with a barebones model and successively adding variables of interest, specifically the interaction variables. First, we included all the control variables in a basic model (Model 1). Firm size is significantly related to the degree of internationalization $(\gamma=0.346$, $p<0.001)$. Manufacturing firms are also more likely to have higher foreign sales $(\gamma=0.820$, $p<0.001)$. Second, we added the independent variable, development of subnational institutions, to Model 2. The results show that subnational institutions have a positive relationship to firms' degree of internationalization $(\gamma=0.388, p<0.05)$, providing strong support for Hypothesis 1.

Hypotheses 2 and 3 predict the moderating effect of political capital on the degree of internationalization. As Model 3 shows, the moderation of political capital with high-level governments on the relationship between subnational institutions and the degree of internationalization is not significant, offering no support to Hypothesis 2. Model 4 shows that the moderation of political capital with low-level governments is significantly positive $(\gamma=0.193, p<0.05)$, in support of Hypothesis 3. In Model 5 (the full model), which includes all the variables and interactions, the results confirm support for Hypotheses 2 and 3. Fig. 1 illustrates the moderation effect of political capital with low-level governments on the relationship between the development of subnational institutions and the degree of internationalization.

---- Insert Table 2 about here ----

---- Insert Figure 1 about here ----

\section{Discussion}


This article shows how subnational institutions in the home country can benefit emerging market entrepreneurial firms' international expansion and how such benefits vary across firms with different types of political capital. By and large, our results from a sample of 760 entrepreneurial firms in China over five years corroborate the central proposition of this study-well-established subnational institutions in a home country facilitate entrepreneurial firms' internationalization, and political capital is important for linking the home market institutional environment and firms' decisions to expand internationally.

We found that entrepreneurial firms' degree of internationalization is positively related to the level of the regional institutional environment in emerging markets. This evidence complements previous research findings that emerging market-based entrepreneurial firms expand overseas to overcome the institutional disadvantages in their home country (Yamakawa et al., 2008). The significant, positive effect of regional institution development on international market expansion also provides strong support for the importance of subnational regions as an additional unit in explaining entrepreneurial firms' internationalization strategies.

This study also argued that the exploitation benefits of home country institutional environments depend on the type of political capital with home governments. We argued that because of the different characteristics of high- and low-level governments, political capital with different types of governments plays different roles in entrepreneurial firms' exploitation of institutional benefits. Political capital with high-level governments enhances entrepreneurial firms' capability of utilizing the institutions, mainly by enhancing firms' creditability and legitimacy; political capital with low-level governments improves entrepreneurial firms' understanding of the institutional environment, largely by 
facilitating knowledge search and transfer. As a result, we proposed that both types of political capital improve entrepreneurial firms' capability of exploiting institutional benefits and thus positively moderate the relationship between regional institutional environmental development and firms' degree of internationalization.

\subsection{Theoretical contributions}

This study makes several important contributions to the literature. First, the study extends prior research by teasing out how macro-level institutional development and firm's micro-level resource-seeking strategies interact to enhance firms' international expansion. Prior research on the home country environment-international expansion relationship has emphasized the power of institutions to determine firms' international investment behavior (Voss et al., 2010; Wan \& Hoskisson, 2003). These studies have explicitly argued that firms benefit equally from home country institutional environments during internationalization and thus have largely ignored the difference in benefits firms receive from their heterogeneous strategies to exploit the institutions.

Our study was motivated by such a dearth of multi-level studies on the institutional environment-internationalization link. In particular, we argued that benefiting from the institutional environment involves a process of exploiting the institutional advantages. This process is difficult because it requires that firms have a wide range of knowledge of institutions and the capability of utilizing these institutions. Thus, how well firms can exploit the benefits of their home country institutional environments during internationalization depends not only on the level of institutional development in the environments but also on the strategies firms use to exploit the benefits.

In our study, we did not treat firms as passive recipients of benefits of well-established 
institutions, but rather recognized the potential of deploying political capital to enhance entrepreneurial firms' alignment with their home environments, which is an important mechanism to enhance firms' capability of utilizing and exploiting institutional benefits in emerging markets. This finding means that embedment within well-developed home country institutional environments is necessary but not sufficient in itself for entrepreneurial firms' to attain specific advantages for international expansion. Consideration of entrepreneurial firms' political capital deployment as a mechanism to facilitate exploitation of home country institutional advantages is important to theory development because it extends conceptions of how institutional environments can influence a range of firm activities from governance to strategy (Lebedev, Peng, Xie, \& Stevens, 2015; Liu, Wang, Zhao, \& Ahlstrom, 2013) and outcomes such as financial and market performance (Jiang, Peng, Yang, \& Mutlu, 2015; McGuinness, Lam, \& Vieito, 2015).

Second, we introduced theoretical insights from the political capital literature to the home country institutional environment and internationalization literature streams. Rather than replicating prior findings in new empirical settings, however, we adapted a political economics perspective to suggest a fresh approach to investigating emerging market-based entrepreneurial firms' internationalization strategies - that is, an approach that emphasizes the significance of political capital in linking home country institutional environments and firm strategies.

This study also makes an important contribution to literature on political capital by extending the influence of political capital on firms' strategic decisions from the domestic market to the international market. In this sense, the integrative views developed in this 
study can be important stepping stones for future theory development in both the political capital and the home country institutional environment literature streams.

Third, this study challenges the premise in prior management research that all types of political capital are equally effective in affecting a firm's strategy making. To emphasize how the power of different types of political capital varies, we differentiated political capital with two levels of home country governments. We then illustrated how these two types of political capital vary in their roles in developing entrepreneurial firms' capabilities of exploiting institutional advantages. In particular, we simultaneously considered the idiosyncratic characteristics of institutional conditions in emerging economies and the heterogeneity of entrepreneurial firms' political capital with high- and low-level governments, respectively.

Moreover, in general conventional international business research explores the influence of between-home-country environmental differences on firms' international expansion and performance (Wan \& Hoskisson, 2003; Yamakawa et al., 2008), while largely ignoring the effects of within-country differences on firms' strategy making. Our findings reveal that entrepreneurial firms' international expansion is greatly dependent on the subnational environment. Thus, we answer Ahlstrom et al.'s (2014) call to develop a more robust assessment of firms' international market expansion level.

Finally, we changed the focus of international entrepreneurial literature from knowledge and asset acquisition in the host country to knowledge and asset acquisition in the home country (Autio, Sapienza, \& Almeida, 2000; McDougall \& Oviatt, 1996; Zahra, Ireland, \& Hitt, 2000). The traditional focus explains how entrepreneurial firms overcome financial and managerial resource deficiencies and disadvantages due to limited business 
experience from a host country perspective (Lu, Zhou, Garry, \& Li, 2010; Wei et al., 2011). Our study provides a new perspective by emphasizing asset and knowledge acquisition from the home country, especially the subnational institutional environments in the home country.

\subsection{Managerial implications}

This study also offers important managerial implications for managers of entrepreneurial firms in emerging markets who are considering entering international markets. Our findings suggest that both the regional institutional environment and firms' resource-seeking strategies are important considerations when making internationalization decisions. Moreover, for entrepreneurial firms in well-developed regional institutional environments, managers should not neglect developing political capital with regional and local governments rather than focusing only on the central government (Ahlstrom et al., 2003; Mann, 1997).

This is true because the former type of political capital directly improves firms' capability of exploiting institutional advantages and navigating the environment while facilitating innovation (Ahlstrom, 2010; Su, Peng, \& Xie, 2016). The Shanghai government, for example, is well-known for providing fast approval for entrepreneurs and new investors while providing good protection for property rights. This is also the case for other businessfriendly local governments, such as Dongguan city and counties in China's southern Guangdong province. In addition to helping firms get started and build legitimacy and social capital, political capital also helps them avoid the many pitfalls associated with weak formal institutions at the central level of government so common in emerging economies (Acemoglu \& Robinson, 2013; Clissold, 2006). 


\subsection{Limitations and further research}

Several promising directions are available for future studies. First, firms face three related questions with regard to international expansion: what market to enter (entry location), how to enter (mode of entry), and when to enter (timing of entry) (Gaba, Pan, \& Ungson, 2002). Further research could examine how the home market institutional environment and firms' political capital influence these decisions.

Second, although China represents a good example of an emerging economy, future studies could examine whether our results hold for entrepreneurial firms from other emerging and newly developed economies. For example, studies could also test the hypotheses with a multiple-country sample and compare whether the integrative influence of the institutional environment and political capital varies across countries.

Third, further research could use other measurements to gauge the level of international expansion to examine the robustness of our results (Abrahamson, 2008). Proxies of the degree of foreign investment used in previous studies include foreign sales to total sales (Geringer, Beamish, \& daCosta, 1989), foreign assets to total assets (Daniels \& Bracker, 1989), and geographic dispersion (similar to the measures used herein) (Lu \& Beamish, 2004). These measurements have varying implications; the first two measures gauge a firm's dependence on foreign markets and foreign resources, respectively (Sanders

\& Carpenter, 1998), while the third measure is a proxy for the cultural and institutional variety an MNC encounters (Johanson \& Vahlne, 1977).

\section{Conclusion}

This study advances the institutional view of internationalization by aligning the 
subnational institutional environment with resource-seeking considerations. Using a large sample of Chinese entrepreneurial firms from 2002 to 2006, we found that a wellestablished subnational institutional environment led to a higher degree of internationalization. Companies operating in emerging economics need to pay attention to the local institutional environment, not only at the national level but also at the subnational level. Furthermore, we argued that political capital with low-level and regional governments contributes to emerging market-based entrepreneurial firms' capability of exploiting institutional benefits by facilitating information search and transfer. Conversely, political capital with high-level (central and top provincial) governments enhances firms' institutional benefit exploitation largely by increasing their credibility and legitimacy. Both types of political capital positively moderate the relationship between the subnational institutional environment and entrepreneurial firms' degree of internationalization. Our study sheds more light on how different levels of political capital can more specifically shape entrepreneurial firms' capability of benefiting from home country subnational institutional environments in internationalization and related strategies. 


\section{References}

Abrahamson, E. (2008). 22 things I hate: Mini rants on management research. Journal of Management Inquiry, 17(4): 422-425.

Acemoglu, D., \& Johnson, S. (2005). Unbundling institutions. Journal of Political Economy, 113 (5): 949-995.

Acemoglu, D., \& Robinson, J. (2013). Why nations fail: The origins of power, prosperity, and poverty. New York: Crown Business.

Ahlstrom, D. (2010). Innovation and growth: How business contributes to society. Academy of Management Perspectives, 24 (3): 11-24.

Ahlstrom, D., Bruton, G. D., \& Lui, S. S. Y. (2000). Navigating China's changing economy: Strategies for private firms. Business Horizons, 43(1): 5-15.

Ahlstrom, D., Bruton, G. D., \& Yeh, K. S. (2008). Private firms in China: Building legitimacy in an emerging economy. Journal of World Business, 43(4): 385-399.

Ahlstrom, D., \& Ding, Z. (2014). Entrepreneurship in China: An overview. International Small Business Journal, 32(6): 610-618.

Ahlstrom, D., Levitas, E., Hitt, M. A., Dacin, M. T., \& Zhu, H. (2014). The three faces of China: Strategic alliance partner selection in three ethnic Chinese economies. Journal of World Business, 49(4): 572-585.

Ahlstrom, D., Young, M. N., Nair, A., \& Law, P. (2003). Managing the institutional environment: Challenges for foreign firms in post WTO China. SAM Advanced Management Journal, 68(2), 41-49.

Arrow, K. J. (1971). Essays in the theory of risk-bearing. Chicago: Markham Publishing Company.

Autio, E., Sapienza, H. J., \& Almeida, J. G. (2000). Effects of age at entry, knowledge intensity, and imitability on international growth. Academy of Management Journal, 43, 909-924.

Blake, A., Deng, Z., \& Rod, F. (2009). How does the productivity of foreign direct investment spill over to local firms in Chinese manufacturing? Journal of Chinese Economic \& Business Studies, 7, 183-197.

Blomstrom, M., \& Kokko, A. (1998). Multinational corporations and spillovers. Journal of Economic Surveys, 12(3): 247-277.

Bruton, G. D., Ahlstrom, D., \& Li, H. (2010). Institutional theory and entrepreneurship: Where are we now and where do we need to move in the future? Entrepreneurship Theory and Practice, 34(3): 421-440

Bruton, G. D., Ahlstrom, D., \& Puky, T. (2009). Institutional differences and the development of entrepreneurial ventures: A comparison of the venture capital industries in Latin America and Asia. Journal of International Business Studies, 40, 762-778.

Bruton, G. D., Peng, M. W., Ahlstrom, D., Stan, C., \& Xu, K. (2015). State-owned enterprises around the world as hybrid organizations. Academy of Management Perspectives, 29(1): 92-114.

Buckley, P. J., \& Casson, M. C. (1998). Analyzing foreign market entry strategies: Extending the internalization approach. Journal of International Business Studies, 29(3): 539-561.

Cai, K. G. (1999). Outward foreign direct investment: A novel dimension of China's 
integration into the regional and global economy. The China Quarterly, 160, 856880.

Carney, M., Gedajlovic, E., \& Yang, X. (2009). Varieties of Asian capitalism: Toward an institutional theory of Asian enterprise. Asia Pacific Journal of Management, 26(3): 361-380.

Chan, C. M., Isobe, T., \& Makino, S. (2008). Which country matters? Institutional development and foreign affiliate performance. Strategic Management Journal, 29, 1179-1205.

Chan, C. M., Makino, S., \& Isobe, T. (2010). Does subnational region matter? Foreign affiliate performance in the United States and China. Strategic Management Journal, 31, 1226-1243.

Chan, K. H., Lin, K. Z., \& Wong, B. (2010b). The impact of government ownership and institutions on the reporting behavior of local auditors in China. Journal of International Accounting Research, 9, 1-20.

Chan, K. S., Dang, V. Q. T., \& Yan, I. K. M. (2012). Chinese firms' political connection, ownership, and financing constraints. Economics Letters, 115, 164-167.

Chao, M. C.-H., \& Kumar, V. (2010). The impact of institutional distance on the international diversity-performance relationship. Journal of World Business, 45(1): 93-103.

Che, J., \& Qian, Y. (1998). Insecure property rights and government ownership of firms. Quarterly Journal of Economics, 113, 467-496.

Chien, S.-S. (2010). Economic freedom and political control in post-Mao China: A perspective of upward accountability and asymmetric decentralization. Asian Journal of Political Science, 18, 69-89.

Child, J., \& Tse, D. K. (2001). Chinas transition and its implications for international business. Journal of International Business Studies, 32, 5-21.

Clissold, T. (2006). Mr. China: A memoir. New York: HarperCollins.

Cuervo-Cazurra, A., \& Genc, M. (2008). Transforming disadvantages into advantages: developing-country MNEs in the least developed countries. Journal of International Business Studies, 39, 957-979.

Daniels, J. D., \& Bracker, J. (1989). Profit performance: Do foreign operations make a difference? Management International Review, 29, 46-56.

Dawar, N., \& Frost, T. (1999). Competing with giants: Survival strategies for local companies in emerging markets. Harvard Business Review, 77, 119-132.

De Soto, H. 1989. The other path. New York: Harper \& Row.

Dikova, D., Jaklič, A., Burger, A., \& Kunčič, A. (2016). What is beneficial for first-time SME-exporters from a transition economy: A diversified or a focused exportstrategy? Journal of World Business, 51(2), 185-199.

Doh, J. P., Luthans, F., \& Slocum, J. (2016). The world of global business 1965-2015: Perspectives on the 50th anniversary issue of the Journal of World Business: Introduction to the special issue. Journal of World Business, 51(1), 1-5.

Dunbar, R. L. M., \& Ahlstrom, D. (1995). Seeking the institutional balance of power: Avoiding the power of a balanced view. Academy of Management Review, 20(1): 171-192.

Faccio, M. (2010). Differences between politically connected and nonconnected firms: a cross-country analysis. Financial Management, 39, 905-928. 
Faccio, M., Masulis, R. W., \& McConnell, J. J. (2006). Political connections and corporate bailouts. Journal of Finance, 61, 2597-2635.

Fan, J. P. H., Wong, T. J., \& Zhang, T. (2007). Politically connected CEOs, corporate governance, and post-IPO performance of china's newly partially privatized firms. Journal of Financial Economics, 84, 330-357.

Francis, B. B., Hasan, I., \& Sun, X. (2009). Political connections and the process of going public: Evidence from China. Journal of International Money \& Finance, 28, 696719.

Frynas, J. G., Mellahi, K., \& Pigman, G. A. (2006). First mover advantages in international business and firm-specific political resources. Strategic Management Journal, 27, 321-345.

Gaba, V., Pan, Y., \& Ungson, G. R. (2002). Timing of entry in international market: An empirical study of U.S. Fortune 500 firms in China. Journal of International Business Studies, 33, 39-55.

Geringer, J. M., Beamish, P. W., \& daCosta, R. C. (1989). Diversification strategy and internationalization: Implications for MNE performance. Strategic Management Journal, 10, 109-119.

Gong, Y., Chow, I. H. S., \& Ahlstrom, D. (2011). Cultural diversity in China: Dialect, job embeddedness, and turnover. Asia Pacific Journal of Management, 28(2): 221-238.

Hatani, F., \& McGaughey, S. L. (2013). Network cohesion in global expansion: An evolutionary view. Journal of World Business, 48(4): 455-465.

Henisz, W. J., \& Delios, A. (2001). Uncertainty, imitation, and plant location: Japanese multinational corporations, 1990-1996. Administrative Science Quarterly, 46, 443475.

Henisz, W. J., \& Delios, A. (2002). Learning about the institutional environment. Advances in Strategic Management, 19, 339-372.

Higgins, M. J., Levy, D., \& Young, A. T. (2006). Growth and convergence across the United States: Evidence from county-level data. Review of Economics \& Statistics, 88, 671-681.

Higgins, M. J., Young, A., \& Levy, D. (2009). Federal, state, and local governments: Evaluating their separate roles in US growth. Public Choice, 139, 493-507.

Hitt, M. A., Ahlstrom, D., Dacin, M. T., Levitas, E., \& Svobodina, L. (2004). The institutional effects on strategic alliance partner selection in transition economies: China vs. Russia. Organization Science, 15(2): 173-185.

Hitt, M. A., Hoskisson, R. E., \& Kim, H. (1997). International diversification: Effects on innovation and firm performance in product-diversified firms. Academy of Management Journal, 40, 767-798.

Hitt, M. A., Li, D., \& Xu, K. (2016). International strategy: From local to global and beyond. Journal of World Business, 51(1): 58-73.

Holmes, R. M., Miller, T., Hitt, M. A., \& Salmador, M. P. (2013). The interrelationships among informal institutions, formal institutions, and inward foreign direct investment. Journal of Management, 39: 531-566.

Jiang, Y., Peng, M. W., Yang, X., \& Mutlu, C. C. (2015). Privatization, governance, and survival: MNE investments in private participation projects in emerging economies. Journal of World Business, 50(2): 294-301.

Johanson, J., \& Vahlne, J.-E. (1977). The internationalization process of the firm: A model 
of knowledge development and increasing foreign market commitments. Journal of International Business Studies, 8, 25-34.

Joshi, A., Liao, H., \& Jackson, S. E. (2006). Cross-level effects of workplace diversity on sales performance and pay. Academy of Management Journal, 49, 459-481.

Judge, W. Q., Jr., \& Zeithaml, C. P. (1992). Institutional and strategic choice perspectives on board involvement in the strategic decision process. Academy of Management Journal, 35, 766-794.

Jun, D., \& Girma, S. (2010). Red capitalists: Political connections and firm performance in China. Kyklos, 63, 530-545.

Kambhampati, U., \& McCann, P. (2007). Regional performance and characteristics of Indian manufacturing industry. Regional Studies, 41(3), 281-294.

Khanna, T., \& Palepu, K. (1997). Why focused strategies may be wrong for emerging markets. Harvard Business Review, 75, 41-51.

Khanna, T., \& Palepu, K. (2000). Is group affiliation profitable in emerging markets? An analysis of diversified Indian business groups. Journal of Finance, 55, 867-891.

Khanna, T., Palepu, K. G., \& Sinha, J. (2005). Strategies that fit emerging markets. Harvard Business Review, 83, 63-76.

Klein, K. J., Dansereau, F., \& Hall, R. J. (1994). Levels issues in theory development, data collection, and analysis. Academy of Management Review, 19, 195-229.

Kogut, B., \& Zander, U. (1993). Knowledge of the firm and the evolutionary theory of the multinational corporation. Journal of International Business Studies, 24, 625-645.

Lebedev, S., Peng, M. W., Xie, E., \& Stevens, C. E. (2015). Mergers and acquisitions in and out of emerging economies. Journal of World Business, 50(4): 651-662.

Li, H., Meng, L., Wang, Q., \& Zhou, L.-A. (2008). Political connections, financing and firm performance: Evidence from Chinese private firms. Journal of Development Economics, 87, 283-299.

Li, H., \& Zhang, Y. (2007). The role of managers' political networking and functional experience in new venture performance: Evidence from China's transition economy. Strategic Management Journal, 28, 791-804.

Li, M. H., Cui, L., \& Lu, J. Y. (2014). Varieties in state capitalism: Outward FDI strategies of central and local state-owned enterprises from emerging economy countries. Journal of International Business Studies, 45, 1-25.

Li, W., He, A., Lan, H., \& Yiu, D. (2012). Political connections and corporate diversification in emerging economies: Evidence from China. Asia Pacific Journal of Management, 29, 799-818.

Liu, J., Uchida, K., \& Gao, R. (2012). Political connections and the long-term stock performance of Chinese IPOs. Journal of International Financial Markets, Institutions \& Money, 22, 814-833.

Liu, Y., Wang, L. C., Zhao, L., \& Ahlstrom, D. (2013). Board turnover in Taiwan's public firms: An empirical study. Asia Pacific Journal of Management, 30(4), 1059-1086.

Lu, J., \& Beamish, P. (2004). International diversification and firm performance: The Scurve hypothesis. Academy of Management Journal, 47, 598-609.

Lu, J., \& Ma, X. (2008). The contingent value of local partner's business group affiliation. Academy of Management Journal, 51(2), 295-314

Lu, J., Xu, B., \& Liu, X. (2009). The effects of corporate governance and institutional environments on export behaviour in emerging economies. Management 
International Review, 49, 455-478.

Lu, Y., Zhou, L., Garry, B., \& Li, W. (2010). Capabilities as a mediator linking resources and the international performance of entrepreneurial firms in an emerging economy. Journal of International Business Studies, 41, 419-436.

Luo, Y., Xue, Q., \& Han, B. (2010). How emerging market governments promote outward FDI: Experience from China. Journal of World Business, 45(1): 68-79.

Ma, H., Lin, S., \& Liang, N. (2011). Corporate political strategies of private Chinese firms. New York: Routledge.

Ma, X., Tong, T. W., \& Fitza, M. (2013). How much does subnational region matter to foreign subsidiary performance? Evidence from Fortune Global 500 corporations' investment in China. Journal of International Business Studies, 44, 66-87.

Makino, S., Isobe, T., \& Chan, C. M. (2004). Does country matter? Strategic Management Journal, 25, 1027-1043.

Mann, J. (1997). Beijing Jeep: A case study of Western business in China. Boulder, CO: Westview Press.

Mascarenhas, B. (1986). International strategies of non-dominant firms. Journal of International Business Studies, 17, 1-25.

McDougall, P., \& Oviatt, B. (1996). New venture internationalization, strategic change, and performance: A follow-up study. Journal of Business Venturing, 11, 23-23.

McGahan, A. M., \& Victer, R. (2010). How much does home country matter to corporate profitability? Journal of International Business Studies, 41, 142-165.

McGuinness, P. B., Lam, K. C. K., \& Vieito, J. P. (2015). Gender and other major board characteristics in China: Explaining corporate dividend policy and governance. Asia Pacific Journal of Management, 32(4): 989-1038.

Meyer, K. E. (2001). Institutions, transaction costs, and entry mode choice in Eastern Europe. Journal of International Business Studies, 32, 357-367.

Meyer, K. E., Estrin, S., Bhaumik, S. K., \& Peng, M. W. (2009). Institutions, resources, and entry strategies in emerging economies. Strategic Management Journal, 30, 61-80.

Meyer, K. E., \& Nguyen, H. V. (2005). Foreign investment strategies and sub-national institutions in emerging markets: Evidence from Vietnam. Journal of Management Studies, 42(1), 63-93.

Meyer, K. E., \& Peng, M. W. (2005). Probing theoretically into Central and Eastern Europe: Transactions, resources, and institutions. Journal of International Business Studies, 36, 600-621.

Monreal-Pérez, J., Aragón-Sánchez, A., \& Sánchez-Marín, G. (2012). A longitudinal study of the relationship between export activity and innovation in the Spanish firm: The moderating role of productivity. International Business Review, 21, 862-877.

Nicolini, M., \& Resmini, L. (2010). FDI spillovers in new EU member states. Economics of Transition, 18, 487-511.

North, D. C. (1990). Institutions, institutional change, and economic performance. Cambridge: Cambridge University Press.

Oi, J. C. (1995). The role of the local state in China's transitional economy. The China Quarterly, 144, 1132-1149.

Okhmatovskiy, I. (2010). Performance implications of ties to the government and SOEs: A political embeddedness perspective. Journal of Management Studies, 47, 1020- 
1047.

Oxley, J. E. (1999). Institutional environment and the mechanisms of governance: The impact of intellectual property protection on the structure of inter-firm alliances. Journal of Economic Behavior \& Organization, 38, 283-309.

Park, S. H., \& Luo, Y. (2001). Guanxi and organizational dynamics: Organizational networking in Chinese firms. Strategic Management Journal, 22, 455-477.

Peng, M. W., \& Hao, C. (2011). Strategic responses to domestic and foreign institutional pressures. International Studies of Management \& Organization, 41, 88-105.

Peng, M. W., \& Heath, P. S. (1996). The growth of the firm in planned economies in transition: Institutions, organizations, and strategic choice. Academy of Management Review, 21(2): 492-528.

Peng, M. W., Sun, S. L., Pinkham, B., \& Chen, H. (2009). The institution-based view as a third leg for a strategy tripod. Academy of Management Perspectives, 23, 63-81.

Peng, M. W., Wang, D. Y. L., \& Yi, J. (2008). An institution-based view of international business strategy: A focus on emerging economies. Journal of International Business Studies, 39, 920-936.

Pepinsky, T. B., \& Wihardja, M. M. (2011). Decentralization and economic performance in Indonesia. Journal of East Asian Studies, 11, 337-371.

Poncet, S. (2005). A fragmented China: Measure and determinants of Chinese domestic market disintegration. Review of International Economics, 13(3), 409-430.

Redfern, K., \& Crawford, J. (2010). Regional differences in business ethics in the People's Republic of China: A multi-dimensional approach to the effects of modernisation. Asia Pacific Journal of Management, 27(2): 215-235.

Sanders, W. M. G., \& Carpenter, M. A. (1998). Internationalization and firm governance: the roles of CEO compensation, top team composition, and board structure. Academy of Management Journal, 41, 158-178.

Saxenian, A. (1994). Regional advantage: Culture and competition in Silicon Valley. Cambridge, MA: Harvard University Press.

Schwens, C., Eiche, J., \& Kabst, R. (2011). The moderating impact of informal institutional distance and formal institutional risk on SME entry mode choice. Journal of Management Studies, 48(2), 330-351.

Scott, W. R. (2013). Institutions and organizations: Ideas, interests, and identities. Thousand Oaks, CA: Sage.

Sheng, Y. (2007). Governing economic openness: Provincial level evidence from China (1972-2002). Comparative Political Studies, 40(4): 405-434.

Sölvell, O. (2015). The Competitive Advantage of Nations 25 years - opening up new perspectives on competitiveness. Competitiveness Review, 25(5): 471-481.

Stata Corporation. (2001). Stata Statistical Software Release 7.0: Programming. College State, TX: Stata Corporation.

Su, Z., Peng, M. W., \& Xie, E. (2016). A strategy tripod perspective on knowledge creation capability. British Journal of Management, 27(1), 58-76.

Suchman, M. C. (1995). Managing legitimacy: Strategic and institutional approaches. Academy of Management Review, 20, 571-610.

Teece, D. J. (1977). Technology transfer by multinational firms: The resource cost of transferring technological know-how. The Economic Journal, 87, 242-261.

Tseng, C.-H., Tansuhaj, P., Hallagan, W., \& McCullough, J. (2007). Effects of firm 
resources on growth in multinationality. Journal of International Business Studies, $38,961-974$.

UNCTAD. (2010). World investment report. New York: United Nations Press.

Voss, H., Buckley, P. J., \& Cross, A. R. (2010). The impact of home country institutional effects on the internationalization strategy of Chinese firms. Multinational Business Review, 18, 25-48.

Vries, M. (2008). Falling between two cracks: The indeterminate character of mid-level government. Public Organization Review, 8, 69-87.

Wan, W. P., \& Hoskisson, R. E. (2003). Home country environments, corporate diversification strategies, and firm performance. Academy of Management Journal, $46,27-45$.

Wei, Y., \& Liu, X. (2006). Productivity spillovers from R\&D, exports and FDI in China's manufacturing sector. Journal of International Business Studies, 37, 544-557.

Wei, Z., Hou, J., Wang, D., \& Wang, L. (2011). How can SMEs leverage political ties and technological innovation capability to acquire government assistance in a transition economy? Journal of General Management, 36, 3-22.

Williamson, O. E. (1985). The economic institutions of capitalism. New York: Free Press.

Wu, J. (2011). Asymmetric roles of business ties and political ties in product innovation. Journal of Business Research, 64, 1151-1156.

$\mathrm{Xu}, \mathrm{C}$. (2011). The fundamental institutions of China's reforms and development. Journal of Economic Literature, 49, 1076-1151.

$\mathrm{Xu}, \mathrm{D} .$, \& Shenkar, O. (2002). Note: Institutional distance and the multinational enterprise. Academy of Management Review, 27(4): 608-618.

Yamakawa, Y., Peng, M. W., \& Deeds, D. L. (2008). What drives new ventures to internationalize from emerging to developed economies? Entrepreneurship: Theory \& Practice, 32, 59-82.

You, J., \& Du, G. (2012). Are political connections a blessing or a curse? Evidence from CEO turnover in China. Corporate Governance: An International Review, 20, 179194.

Young, M. N., Ahlstrom, D., Bruton, G. D., \& Rubanik, Y. 2011. What do firms from transition economies want from their strategic alliance partners? Business Horizons, 54(2): 163-174.

Zahra, S. A., Ireland, R. D., \& Hitt, M. A. (2000). International expansion by new venture firms: International diversity, mode of market entry, technological learning, and performance. Academy of Management Journal, 43, 925-950.

Zhan, V. J. (2009). Decentralizing China: Analysis of central strategies in China's fiscal reforms. Journal of Contemporary China, 18, 445-462.

Zhou, C., Delios, A., \& Yang, J. Y. (2002). Locational determinants of Japanese foreign direct investment in China. Asia Pacific Journal of Management, 19(1): 63-86. 
Table 1

Statistics and correlation matrix of variables. ${ }^{\text {a }}$

\begin{tabular}{|c|c|c|c|c|c|c|c|c|c|c|c|c|c|c|c|c|}
\hline & & $\mathrm{M}$ & $\mathrm{SD}$ & 1 & 2 & 3 & 4 & 5 & 6 & 7 & 8 & 9 & 10 & 11 & 12 & 13 \\
\hline 1 & Firm size & 4.177 & 1.270 & & & & & & & & & & & & & \\
\hline 2 & Year & 18.220 & 29.583 & 0.031 & & & & & & & & & & & & \\
\hline 3 & Debt ratio & 1.129 & 4.114 & 0.106 & -0.000 & & & & & & & & & & & \\
\hline 4 & Return on equity & 0.432 & 0.667 & 0.057 & 0.049 & 0.008 & & & & & & & & & & \\
\hline 5 & Foreign equity & 0.567 & 5.943 & 0.052 & -0.014 & -0.016 & -0.014 & & & & & & & & & \\
\hline 6 & $\mathrm{R} \& \mathrm{D}$ & 0.098 & 0.276 & 0.010 & 0.093 & 0.050 & 0.041 & -0.025 & & & & & & & & \\
\hline 7 & Restructure & 0.159 & 0.366 & 0.073 & -0.079 & -0.016 & -0.023 & 0.005 & -0.018 & & & & & & & \\
\hline 8 & Industry-Manuf & 0.453 & 0.498 & 0.204 & -0.036 & 0.042 & 0.044 & 0.057 & 0.008 & 0.053 & & & & & & \\
\hline 9 & Industry-Tech & 0.012 & 0.110 & -0.021 & 0.018 & 0.000 & 0.038 & -0.011 & 0.059 & -0.027 & -0.101 & & & & & \\
\hline 11 & Age & 50.531 & 58.646 & -0.066 & 0.006 & -0.004 & 0.013 & -0.004 & 0.046 & 0.002 & 0.037 & -0.005 & & & & \\
\hline 12 & Education & 3.408 & 1.164 & 0.103 & -0.101 & -0.004 & 0.010 & 0.015 & 0.009 & -0.008 & -0.045 & 0.084 & -0.081 & & & \\
\hline 13 & $\begin{array}{l}\text { Political capital with a } \\
\text { high-level government }\end{array}$ & 0.023 & 0.156 & 0.175 & 0.004 & 0.058 & 0.023 & 0.032 & 0.041 & 0.029 & 0.025 & -0.016 & 0.004 & 0.036 & & \\
\hline 14 & $\begin{array}{l}\text { Political capital with a } \\
\text { low-level government }\end{array}$ & 0.729 & 0.649 & 0.258 & -0.009 & 0.039 & -0.011 & 0.012 & -0.021 & 0.055 & 0.004 & 0.009 & -0.033 & 0.065 & -0.078 & \\
\hline \multirow[t]{2}{*}{15} & $\begin{array}{l}\text { Degree of } \\
\text { internationalization }\end{array}$ & 0.024 & 0.123 & 0.067 & -0.042 & 0.019 & -0.036 & 0.046 & -0.019 & 0,016 & 0.097 & -0.022 & -0.006 & 0.024 & 0.027 & 0.030 \\
\hline & & $\mathrm{M}$ & SD & 1 & 2 & 3 & 4 & & & & & & & & & \\
\hline 1 & Subnational institution & 0.568 & 1.962 & & & & & & & & & & & & & \\
\hline 2 & LnPopulation & 8.407 & 0.655 & 0.034 & & & & & & & & & & & & \\
\hline 3 & Patent ratio & 1.879 & 0.413 & 0.333 & -0.252 & & & & & & & & & & & \\
\hline 4 & Regional education & 0.879 & 0.041 & 0.228 & 0.121 & 0.178 & & & & & & & & & & \\
\hline 5 & Special economic zone & 1.129 & 0.560 & 0.159 & 0.104 & -0.200 & 0.099 & & & & & & & & & \\
\hline
\end{tabular}

a 1,133 observation in 64 groups. 


\section{Table 2}

Regression results for emerging market firms' foreign sales intensity. ${ }^{\text {a }}$

\begin{tabular}{|c|c|c|c|c|c|}
\hline & Model 1 & Model 2 & Model 3 & Model 4 & Model 5 \\
\hline Subnational institution & & $0.388(0.122)^{* * *}$ & $0.389(0.122)^{* * *}$ & $0.374(0.125)^{* *}$ & $0.376(0.126)^{* *}$ \\
\hline $\begin{array}{l}\text { Subnational institution } \\
\times \text { Political capital with a } \\
\text { high-level government }\end{array}$ & & & $0.024(0.112)$ & & $0.041(0.112)$ \\
\hline $\begin{array}{l}\text { Subnational institution } \\
\times \text { Political capital with a } \\
\text { low-level government }\end{array}$ & & & & $0.193(0.089)^{*}$ & $0.196(0.090)^{*}$ \\
\hline $\begin{array}{l}\text { Political capital with a } \\
\text { high-level government }\end{array}$ & $-0.067(0.091)$ & $-0.079(0.090)$ & $-0.080(0.090)$ & $-0.077(0.090)$ & $-0.078(0.090)$ \\
\hline $\begin{array}{l}\text { Political capital with a } \\
\text { low-level government }\end{array}$ & $0.166(0.095) \dagger$ & $0.161(0.095) \dagger$ & $0.162(0.095) \dagger$ & $0.184(0.095) \dagger$ & $0.184(0.095) \dagger$ \\
\hline LnPopulation & $-0.205(0.215)$ & $-0.087(0.156)$ & $-0.087(0.156)$ & $-0.096(0.161)$ & $-0.095(0.161)$ \\
\hline Patent ratio & $-0.011(0.127)$ & $-0.105(0.129)$ & $-0.106(0.129)$ & $-0.089(0.130)$ & $-0.091(0.130)$ \\
\hline Education & $-0.203(0.215)$ & $-0.429(0.204)^{*}$ & $-0.429(0.204)^{*}$ & $-0.411(0.206)^{*}$ & $-0.409(0.206)^{*}$ \\
\hline Special economic zone & $-0.079(0.143)$ & $-0.176(0.111)$ & $-0.177(0.111)$ & $-0.183(0.114)$ & $-0.184(0.114)$ \\
\hline Firm size & $0.346(0.098)^{* * *}$ & $0.338(0.097)^{* * *}$ & $0.337(0.097)^{* * *}$ & $0.337(0.097)^{* * *}$ & $0.334(0.097)^{* * *}$ \\
\hline Year & $-0.079(0.089)$ & $-0.081(0.089)$ & $-0.080(0.089)$ & $-0.080(0.089)$ & $-0.079(0.089)$ \\
\hline Debt/equity ratio & $0.033(0.088)$ & $0.037(0.088)$ & $0.037(0.088)$ & $0.041(0.088)$ & $0.040(0.088)$ \\
\hline Return on equity & $-0.159(0.080)^{*}$ & $-0.157(0.080)^{*}$ & $-0.157(0.080)^{*}$ & $-0.155(0.078)^{*}$ & $-0.154(0.079)^{*}$ \\
\hline Foreign equity & $0.039(0.088)$ & $0.039(0.089)$ & $0.038(0.089)$ & $0.034(0.088)$ & $0.033(0.088)$ \\
\hline $\mathrm{R} \& \mathrm{D}$ & $-0.049(0.089)$ & $-0.042(0.089)$ & $-0.042(0.089)$ & $-0.033(0.088)$ & $-0.033(0.089)$ \\
\hline Restructure & $0.031(0.243)$ & $0.050(0.242)$ & $0.052(0.242)$ & $0.044(0.241)$ & $0.048(0.241)$ \\
\hline Industry-Manuf & $0.820(0.185)^{* * *}$ & $0.798(0.184)^{* * *}$ & $0.797(0.184)^{* * *}$ & $0.799(0.184)^{* * *}$ & $0.799(0.184)^{* * *}$ \\
\hline Industry-Tech & $-0.679(0.801)$ & $-0.655(0.802)$ & $-0.655(0.802)$ & $-0.690(0.800)$ & $-0.691(0.800)$ \\
\hline Age & $0.009(0.087)$ & $0.002(0.088)$ & $-0.002(0.090)$ & $-0.006(0.090)$ & $-0.006(0.087)$ \\
\hline Regional education & $0.136(0.090)$ & $0.129(0.090)$ & $0.129(0.090)$ & $0.143(0.090)$ & $0.145(0.090)$ \\
\hline Intercept & $-11.067(0.185)^{* * *}$ & $-10.965(0.158)^{* * *}$ & $-10.966(0.158)^{* * *}$ & $-10.938(0.162)^{* * *}$ & $-10.939(0.162)^{* * *}$ \\
\hline Log-likelihood & -2831.1903 & -2828.9542 & -2828.9542 & -2826.6545 & -2826.5885 \\
\hline
\end{tabular}

${ }^{\mathrm{a}} 1,133$ observation in 64 groups.

$+p<0.10 ; * p<0.05 ; * * p<0.01 ; * * * p<0.001$. Two-tailed tests. 
Fig. 1. The moderation effect of political capital with low-level governments on the relationship between the development of subnational institutions and degree of Internationalization.

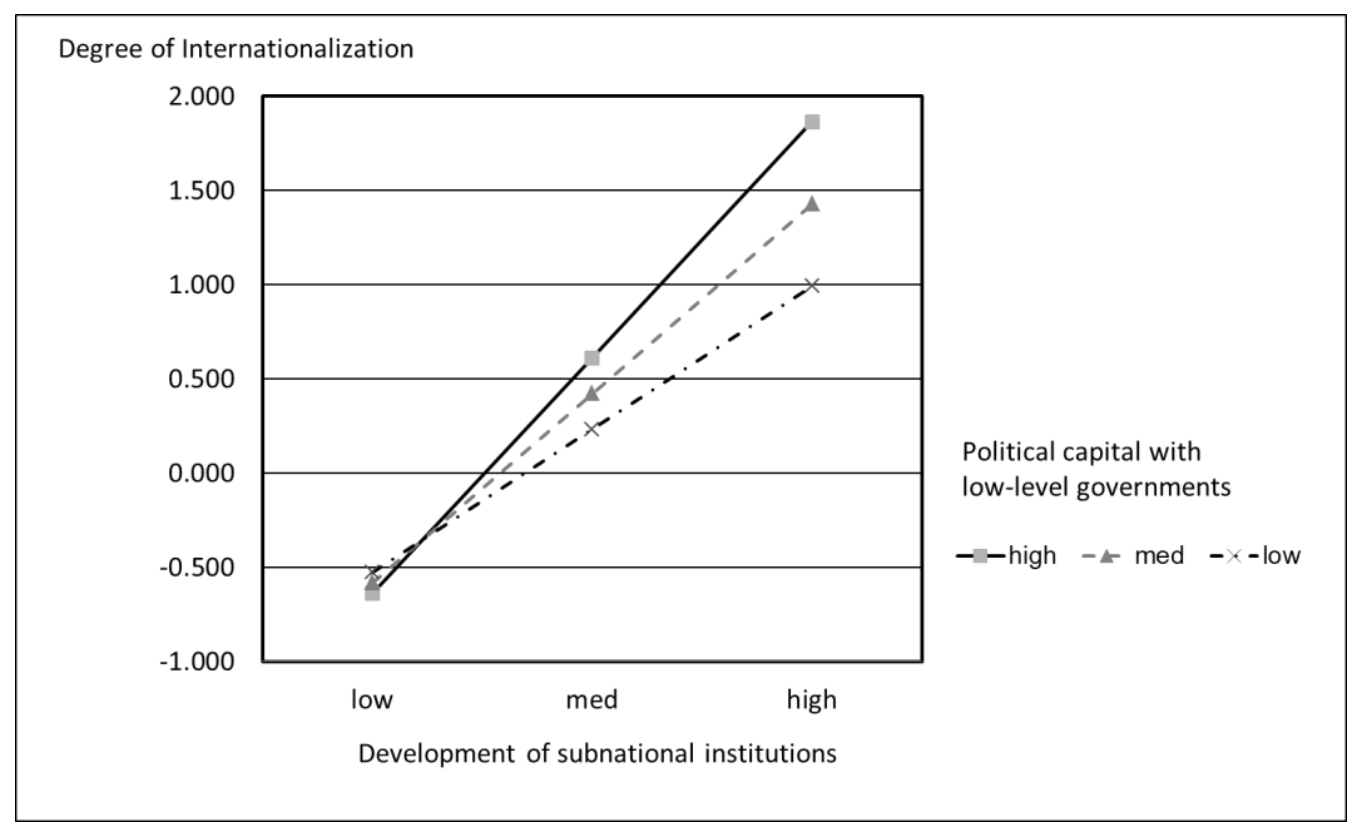

